Андрій Зельницький, кандидат педагогічних наук, професор Національний університет оборони України імені Івана Черняховського, м. Київ ORCID ID 0000-0002-3910-7329

Олег Заболотний, кандидат військових наук, доцент Національний університет оборони України імені Івана Черняховського, м. Київ ORCID ID 0000-0001-8020-4721

Надія Шабатіна,

Національний університет оборони України імені Івана Черняховського, м. Київ ORCID ID 0000-0002-5066-9517

DOI: 10.33099/2617-1775/2019-02/82-91

\title{
ЗАКОНИ ДИДАКТИКИ: СТАН І ТЕНДЕНЩЇ̈ РОЗВИТКУ У СФЕРІ ВИЩОЇ ВІЙСЬКОВОЇ ОСВІТИ
}

У статті досліджуються актуальні проблеми щодо визначення структури, сутності та змісту основних законів дидактики у сфері вищої військової освіти в умовах модернізації вітчизняної вищої військової школи, а також у зв'язку з необхідністю підвищення ефективності функиіонування системи військової освіти та якості підготовки військових фахівиів відповідно до вимог професіоналізаиії сил оборони з максимальним використанням досвіду застосування передових технологій $і$ методик підготовки здобувачів військової освіти в арміях країн-членів НАТО. Дослідження базується на розкритті сутності $і$ змісту педагогічних понять щцодо забезпечення $і$ гарантування якості вищої військової освіти як ијлісної системи.

Ключові слова: закони дидактики; забезпечення якості вищої військової освіти; гарантування якості вищої військової освіти; компетентність здобувача вищої військової освіти.

Постановка проблеми. Комплексний аналіз поточного стану основних законів дидактики, а саме: соціальної зумовленості цілей, змісту і методів навчання; виховного i розвивального навчання; зумовленості навчання i виховання характером діяльності тих, хто навчається; цілісності і єдності педагогічного процесу; єдності і взаємозв'язку теорії і практики навчання; єдності і взаємообумовленості індивідуальної і колективної організації навчальної діяльності та ін. свідчить про те, що представлені закони в цілому забезпечують об'єктивний, необхідний, загальний i сумісний зв'язок i взаємозв'язок між завданнями, змістом і методами педагогічного процесу та його результатами.

Разом із тим, варто зазначити, що у цих законах не йдеться про педагогічні категорії, пов'язані із забезпеченням та гарантуванням якості освіти, хоча саме ці поняття $\epsilon$ на теперішній час розвитку педагогічної науки найбільш пріоритетними та малодослідженими. Відтак, подальший розвиток дидактики, в тому числі - у сфері вищої (вищої військової) освіти має враховувати зазначені тенденції. 
Аналіз останніх досліджень і публікацій. Наукове обгрунтування законів дидактики пропонують у своїх фундаментальних працях зарубіжні вчені: Б. Блум, Дж. Керрол, Д. Брунер, Г. Гейс, В. Коскареллі та ін.

Вітчизняні підходи до тлумачення законів дидактики та якості освіти відображено в наукових працях В. Андрущенка, В. Безпалька, А. Вітченка, С. Гончаренка, В. Докучаєвої, В. Кременя, О. Пометун, С. Сисоєвої, В. Ягупова та ін.

Мета статті - дослідити сутність, зміст та взаємозв'язки основних законів дидактики у цілісній системі якості вищої освіти з урахуванням прояву нових тенденцій у педагогіці вищої школи.

Методи дослідження: системний аналіз і синтез, індукція та дедукція, порівняння, класифікація, узагальнення й систематизація; ідеалізації та абстрагування.

Виклад основного матеріалу. Розглядаючи в теоретичному плані проблему сутності та змісту педагогічних і дидактичних законів, слід, перш за все, визначитися із поняттям “теорія" (від грец. teoria - розгляд, дослідження). У широкому сенсі - це розгорнуте вчення, комплекс поглядів, уявлень, ідей, пов'язаних із спробами пояснення чи інтерпретації певної предметної галузі (проблемного поля). У більш строгому і спеціальному смислі - форма організації наукового знання, що дає цілісне уявлення про закономірності певної галузі дійсності. За своєю структурою теорія являє собою систему законів відповідної науки. Ця система вибудовується таким чином, що деякі із законів, що мають найбільш загальний характер, складають ії основу, інші підпорядковуються основним чи виводяться 3 них за логічними правилами. Сфера істинності теорії встановлюється і уточнюється в процесі ії̈ практичного застосування. За межами цієї сфери теорія втрачає свої пізнавальні функції [1, c.709].

Отже, ядром будь-якої наукової теорії $є$ закони відповідної науки як сутнісні, необхідні, стійкі, повторювані зв'язки (відношення) між явищами. До найважливіших рис закону слід віднести: необхідність, всезагальність, повторюваність та інваріантність [1, с. 243]. Існують три основних типи законів: всезагальні, або універсальні (закони діалектики); загальні для великих груп явищ (напр., закон збереження і перетворення енергії, закон природного відбору); специфічні, або часткові (окремі), до яких можна віднести й закони педагогіки. Між загальними i частковими законами існує діалектичний взаємозв'язок: загальні закони діють через часткові, а останні являють собою прояв загальних.

Щодо особливостей застосування законів педагогічної науки, то слід зважати на те, що вони спрямовані на певний предмет, специфічні об'єкти і суб'єкти. Так, предметом педагогіки як науки є навчання, виховання і освіта. Об'єктом науки з точки зору методології суспільних наук $\epsilon$ те, на що дана наука здійснює свій вплив і що змінюється внаслідок цього. Відтак, об'єктом педагогічної науки не $\epsilon$ освіта, наука, виховання як такі, не $\epsilon$ людина (бо людину як таку ніхто не має право змінювати, пристосовувати, адаптовувати до 
своїх уподобань). Об'єктом педагогіки є особистість людини. Суб'єктами педагогічної діяльності (в суспільних науках - це те, що бере участь у процесі, а не лише відчувають його вплив) вважаються ті, хто виконує педагогічні функції у суспільстві, і з іншого боку ті, хто здобувають певні знання в системі освіти. У теорії педагогіки є чимало тлумачень поняття “закон” та визначень його сутності. Педагогічний закон - об’єктивний, необхідний, загальний і сумісний зв'язок і взаємозв'язок між завданнями, змістом і методами педагогічного процесу та його результатами, що виявляються в зміні знань, умінь, переконань, поведінки.

У працях сучасних учених С. Архангельского, Ю. Бабанського, В. Бондаря, Б. Гершунського, В. Загв'язинського, І. Лернера, М. Махмутова, М. Скаткіна, I. Підласого та інших визначено певні закони навчання, що отримали визнання науково-педагогічної громадськості. Серед них:

1. Закон соціальної обумовленості цілей, змісту i методів навчання розкриває об'єктивний процес визначального впливу суспільних відносин, соціального ладу на формування всіх елементів виховання і навчання. Мова йде про те, щоб, використовуючи цей закон, повно i оптимально перевести соціальне замовлення на рівень педагогічних засобів і методів.

2. Закон виховного і розвивального навчання. Розкриває співвідношення оволодіння знаннями, способами діяльності та всебічного розвитку особистості.

3. Закон зумовленості навчання і виховання характером діяльності тих, хто навчається, розкриває співвідношення між педагогічним керівництвом i розвитком власної активності особистості, між способами організації навчання та його результатами.

4. Закон цілісності і єдності педагогічного процесу - розкриває співвідношення частини i цілого в педагогічному процесі, необхідність гармонійної єдності раціонального, емоційного, інформаційного й пошукового, змістового, операційного і мотиваційного компонентів тощо.

5. Закон єдності і взаємозв'язку теорії і практики навчання - Означає, що будь-яке наукове знання, пряме або опосередковане, спрямоване на застосування на практиці (та й базується, зрештою, на ній). Звідси необхідність спиратися на суспільну практику й життєвий досвід студентів, конкретизовувати й застосовувати наукові положення на практиці, наскільки дає змогу специфіка матеріалу, підготовленість студентів та умови навчання.

6. Закон єдності і взаємообумовленості індивідуальної і колективної організації навчальної діяльності. Ці види організації діяльності можуть бути розділені в часі або поєднуватися, (відповідати принципу взаємопроникнення). Певному видові діяльності на певному етапі можна віддавати перевагу, але вони мають не заперечувати, а доповнювати один одного.

Представлені закони носять, здебільшого, всезагальний, філософський характер. Застосування зазначених законів до проведення конкретних педагогічних досліджень $€$ досить проблематичним, хоча наука ставить за мету виявлення законів, згідно з якими об'єкти можуть перетворюватися в процесі діяльності людини Не дуже застосовуваними для вирішення нагальних 
педагогічних проблем виявилися й прийняті науковою спільнотою закони дидактики, які, до того ж, не спираються на математично виражені твердження. Окрім того, у жодному з цих законів немає згадки про найважливіші, на думку авторів, педагогічні категорії: “якість освіти”, “якість освітньої діяльності”, “забезпечення якості освіти”, “гарантування якості освіти”, “компетентність здобувача освіти ". Хоча саме ці поняття є визначальними при забезпеченні якості підготовки фахівців як пріоритетного напряму педагогіки.

На то є певні об'єктивні причини. Педагогічні закони проявляються в умовах впливу на процеси навчання і виховання великої кількості зовнішніх i внутрішніх чинників, а тому не завжди дають чітко визначений, гарантований результат (рис. 1). Вони, як правило, мають прогностичний, імовірнісний, стохастичний характер на відміну, скажімо, від фізичних, хімічних, біологічних законів. С й така особливість, що в соціальній сфері прояви закону складно побачити, відстежити і зафіксувати. Одні й ті самі чинники, закономірності педагогічного процесу в різних умовах, з різними суб'єктами можуть давати зовсім різні, а інколи й протилежні, наслідки.

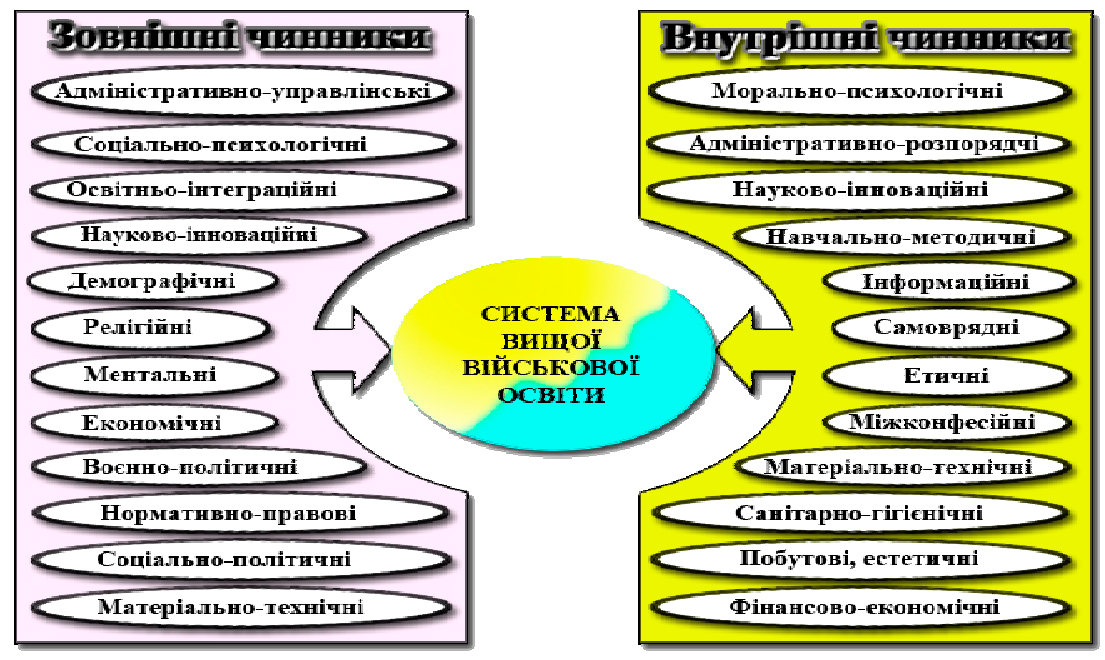

Рис. 1 Зовнішні та внутрішні чинники впливу на якість освіти

У зв’язку з викладеним постає нагальна потреба привнесення в дидактику, у тому числі - у воєнну дидактику, таких законів, що відповідають сучасним потребам педагогічної практики.

Зважаючи на специфіку освіти у військовій сфері, систему вищої військової освіти можна представити як цілісну сукупність взаємопов'язаних компонентів освітньої діяльності вищих військових навчальних закладів (далі ВВН3), що спрямована на організацію, всебічне забезпечення та реалізацію освітнього процесу задля досягнення здобувачами вищої військової освіти визначеного рівня якості освіти.

Щодо якості освіти, то під цим поняттям слід розуміти відповідність результатів навчання вимогам, встановленим законодавством, відповідним стандартом освіти. У свою чергу, результати навчання являють собою знання, уміння, навички, способи мислення, погляди, цінності, інші особисті якості, набуті у процесі навчання, виховання та розвитку, які можна ідентифікувати, 
спланувати, оцінити і виміряти та які особа здатна продемонструвати після завершення освітньої програми або окремих освітніх компонентів [2]. Це визначення $є$ ключовим поняттям у розумінні категорії “Якість підготовки військових фахівців ".

Важливим для цілісного сприйняття зазначеної категорії $є$ розуміння поняття “Якість освітньої діяльності”, сутність якого визначається рівнем організації, забезпечення та реалізації освітнього процесу, що забезпечує здобуття особами якісної освіти та відповідає вимогам, встановленим законодавством [2].

Систему забезпечення якості освіти в Законі України "Про вищу освіту" представлено такими структурними складниками [2]:

система забезпечення вищими навчальними закладами якості освітньої діяльності та якості вищої освіти (система внутрішнього забезпечення якості);

системи зовнішнього забезпечення якості освітньої діяльності вищих навчальних закладів та якості вищої освіти;

система забезпечення якості діяльності Національного агентства із забезпечення якості вищої освіти i незалежних установ оцінювання та забезпечення якості вищої освіти.

Система внутрішнього забезпечення якості включає:

визначення принципів та процедур забезпечення якості вищої освіти;

здійснення моніторингу та періодичного перегляду освітніх програм;

щорічне оцінювання здобувачів вищої освіти, науково-педагогічних i педагогічних працівників вищого навчального закладу та регулярне оприлюднення результатів таких оцінювань на офіційному веб-сайті вищого навчального закладу, на інформаційних стендах та в будь-який інший спосіб;

забезпечення підвищення кваліфікації педагогічних, наукових і науковопедагогічних працівників;

забезпечення наявності необхідних ресурсів для організації освітнього процесу, у тому числі самостійної роботи студентів, за кожною освітньою програмою;

забезпечення наявності інформаційних систем для ефективного управління освітнім процесом;

забезпечення публічності інформації про освітні програми, ступені вищої освіти та кваліфікації і забезпечення ефективної системи запобігання та виявлення академічного плагіату у наукових працях працівників вищих навчальних закладів і здобувачів вищої освіти, інших процедур і заходів.

Отже, ключовими компонентами військової освіти виступають: “система військової освіти”, “якість підготовки військових фахівців”, “якість освітньої діяльності” та “якість освіти”, модель взаємозв'язку яких представлено в системі підготовки військових фахівців у ВВНЗ на рис. 2.

У розробленій моделі представлено нові поняття, що, з-поміж інших, більшою мірою впливають на формування якісних характеристик кадрового потенціалу в системі вищої військової освіти. Серед них найбільш значущими $є$ 
такі: забезпечення якості освітньої діяльності та якості освіти; політика гарантування якості підготовки військових фахівців; компетентність.

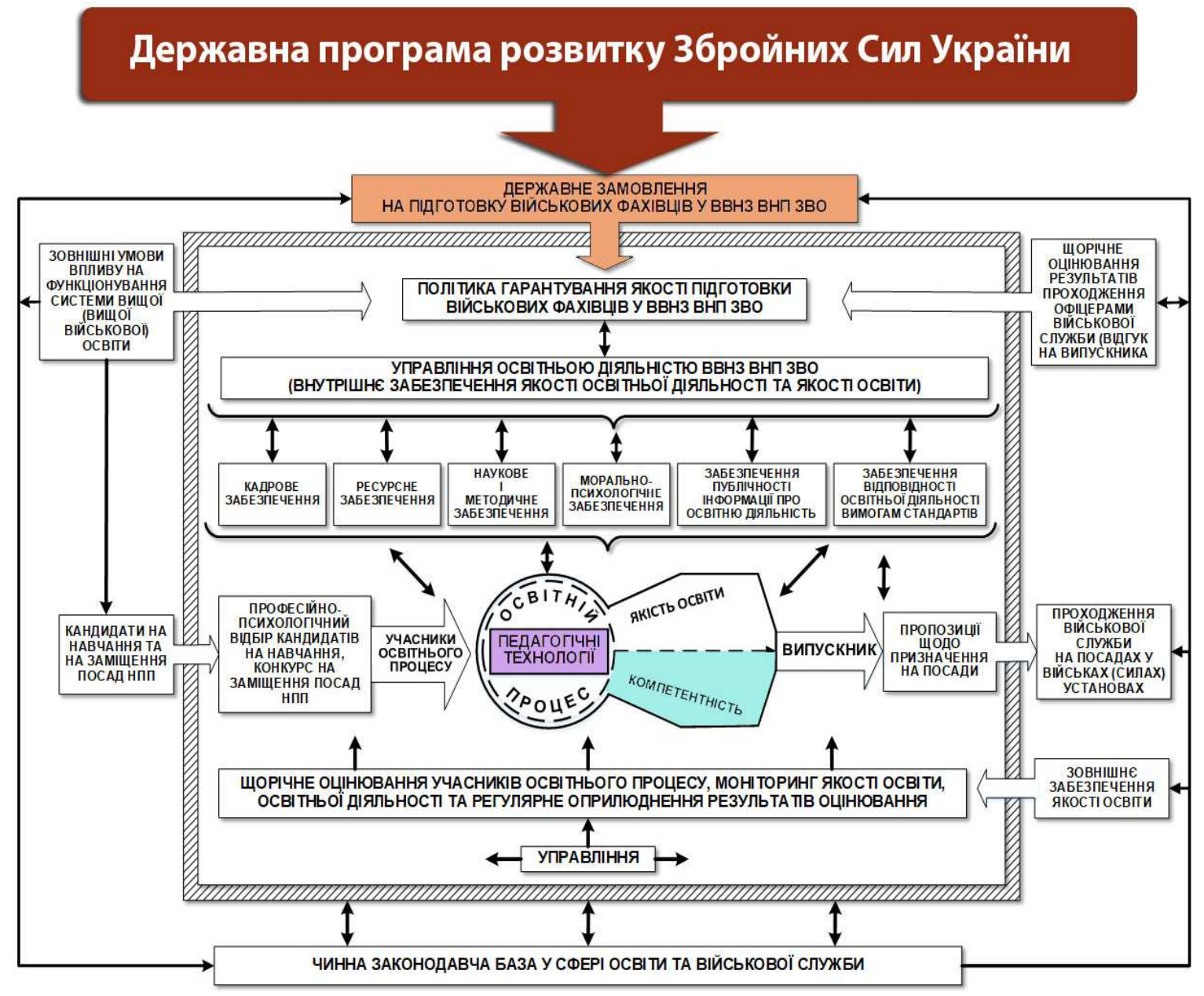

Рис. 2. Модель системи якості військової освіти

Тобто, йдеться про сутність і зміст складників процесу забезпечення та гарантування якості освіти (англ. quality assurance education), що цілком відповідає стратегічному курсу України на приведення вищої освіти у відповідність до європейських, а військової - до євроатлантичних стандартів.

У 2000 році в Гельсінкі країнами-учасниками Болонської угоди (включно 3 Україною), була заснована Свропейська асоціація забезпечення (гарантування) якості вищої освіти під назвою (European Network for Quality Assurance in Higher Education) - організація, що здійснює незалежний контроль якості освіти та освітньої діяльності навчальних закладів. Поняття "Assurance" перекладається 3 англійської і як “забезпечення”, і як “гарантування". Аналогічно, у Великому тлумачному словнику сучасної української мови поняття "забезпечувати" витлумачено як - створювати надійні умови для здійснення чого-небудь; гарантувати щось [3, с.281].

У вітчизняній законодавчій базі термін "гарантування якості освіти" вперше з'явився в Законі України “Про освіту” (Розділ V - Забезпечення якості освіти) [4]. Тобто через 17 років після створення ENQA - без жодних 
коментарів щодо суті, структури і механізмів упровадження цієї категорії в педагогічну практику вищої школи. До того ж поняття “гарантування" введене як одна з чотирьох задекларованих у зазначеному законі цілей.

У Великому тлумачному словнику сучасної української мови поняття "гарантія" визначено як порука в чомусь, передбачені законом чи угодою (домовленістю) зобов'язання, за яким юридична чи фізична особа відповідає за виконання певної угоди [3, с.173]. Адаптуємо поняття “забезпечення" i "гарантування" до особливостей функціонування системи вищої військової освіти. "Забезпечення", у межах цієї системи, виступає як процес створення необхідних умов для досягнення визначених цілей освіти, а "гарантування" (гарантія) - як порука ВВНЗ за якість освіти та відповідальність за досягнення здобувачами вищої військової освіти певних результатів навчання. Отже, гарантія якості вищої військової освіти у контексті результатів навчання - це порука та відповідальність ВВНЗ щодо виконання зобов'язань 3 підготовки слухачів (курсантів) зі ступенем сформованості визначених компетентностей в кожного 3 них не нижче встановленого рівня [5]. У даному контексті компетентність являє собою інтегральний показник якості підготовки здобувача вищої військової освіти як доведена ним здатність до самоосвіти, готовність до виконання функціональних обов'язків на посаді призначення у військах (силах) в умовах мирного i воєнного часу на основі творчого застосування здобутих знань, сформованих навичок та умінь, інших професійно важливих якостей i ціннісних орієнтацій відповідно до стандартів освіти $[6$, с.75-76].

3 урахуванням зазначеного, сутність і зміст законів дидактики щодо якості вищої військової освіти можна представити так (таблиця 1).

Таблиця 1

\section{Сутність і зміст законів дидактики щодо якості вищої військової освіти}

\begin{tabular}{|c|c|c|}
\hline № & Назва закону & Сутність закону \\
\hline 1 & $\begin{array}{l}\text { Закон зумовленості якості } \\
\text { вищої } \text { військової освіти } \\
\text { якістю створених умов, в } \\
\text { яких функціонує система } \\
\text { військової освіти. }\end{array}$ & $\begin{array}{l}\text { Закон розкриває вплив зовнішніх та внутрішніх умов, в } \\
\text { яких функціонує система вищої військової освіти, на } \\
\text { якість підготовки здобувачів вищої військової освіти. }\end{array}$ \\
\hline 2 & $\begin{array}{l}\text { Закон гарантування якості } \\
\text { вищої військової освіти. }\end{array}$ & 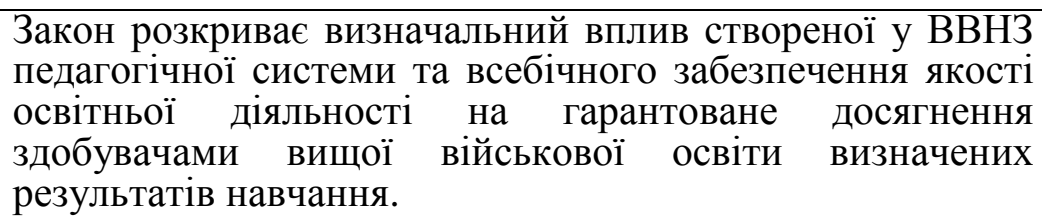 \\
\hline
\end{tabular}

\section{ЛITЕРАТУРА}

1. Новейший философский словарь / Сост. А. А. Грицанов. - Мн.: Изд. В. М. Скакун, 1998. - 896 c.

2. Закон України «Про вищу освіту» [Електронний ресурс]. - Режим доступу: htpp://zakon0.rada.gov.ua/lavs/show/1556-18. 
3. Великий тлумачний словник сучасної української мови / Уклад. і голов. ред. В. Т. Бусел. К.; Ірпінь: ВТФ “Перун”, 2001. - 1440 с.

4. Закон України «Про освіту» [Електронний ресурс]. - Режим доступу: htpp://zakon0.rada.gov.ua/lavs/show/2145-i9,

5. Зельницький А. М., Концептуальні засади гарантування якості підготовки майбутніх офіцерів Збройних Сил України у вищих військових навчальних закладах. Вісник Черкаського університету. Серія пед. науки. - Ч., 2017. - № 6. - С. 71-83.

6. Моніторинг якості підготовки військових фахівців у вищих військових навчальних закладах та військових навчальних підрозділах вищих навчальних закладів Збройних Сил України: наук.-метод. посіб. / А. М. Зельницький, О. А. Заболотний, Ю. І. Приходько та ін.; за заг. ред. І. В. Толока.: ХНУПС, 2017. -120 с.

\section{REFERENCES}

1. Noveyshiy filosofskiy slovar' [New Philosophical Dictionary]/ Sost. A. A. Gritsanov. Mn.: Izd. V. M. Skakun, 1998. - 896 s.

2. Pro vyschu osvitu: Zakon Ukrainy vid 01.07.2014. №1556-VII [On Higher Education: Law of Ukraine from 01.07.2014 №1556-VII] (2017) URL: htpp://zakon0.rada.gov.ua/lavs/show/155618.(in Ukrainian)

3. Velykyy tlumachnyy slovnyk suchasnoyi ukrayinskoyi movy [Definition Dictionary of Modern Ukrainian Language] / uklad. i holov. red. V.T. Busel. - K.; Irpin $\square$ : VTF «Perun», 2001. 1440 s.(in Ukrainian).

4. Pro osvitu: Zakon Ukrainy vid 05.09.2017r. №1556-VII [On Education: Law of Ukraine from 05.09.2017 №2145-VII] (2017) URL: htpp://zakon0.rada.gov.ua/lavs/show/2145-i9.

5. 10. Zelnytskyi, A. M. (2017), Kontseptualni zasady harantuvannia yakosti pidhotovky maibutnikh ofitseriv Zbroinykh Syl Ukrainy u vyshchykh viiskovykh navchalnykh zakladakh. Visn. Cherkask. un-tu. Seriia ped. nauky. [Conceptual Basis of Guaranteeing of Quality of Future Officers' of Armed Forces of Ukraine in Higher Military Educational Institutions Training ] P.7183. (in Ukrainian)

6. Zelnytskyi, A.M., Zabolotnyi, O.A., Prykhodko, Yu.I. (2017). Monitorynh yakosti pidhotovky viiskovykh fakhivtsiv u vyshchykh viiskovykh navchalnykh zakladakh ta viiskovykh navchalnykh pidrozdilakh vyshchykh navchalnykh zakladiv Zbroinykh Syl Ukrainy [Monitoring of Training Quality of Military Specialists in Higher Military Educational Establishments and Military Educational Units of Higher Educational Institutions of the Armed Forces of Ukraine] Kharkiv : KhNUPS, 120 (in Ukrainian).

\section{РЕЗЮМЕ}

Андрей Зельницкий, кандидат педагогических наук, профессор Национальный университет обороны Украины имени Ивана Черняховского, г. Киев

Олег Заболотный,

кандидат военных наук, доцент

Национальный университет обороны Украины имени Ивана Черняховского, г. Киев

Надежда Шабатина,

Национальный университет обороны Украины имени Ивана Черняховского, г. Киев

\section{Законы дидактики: состояние и тенденции развития в сфере высшего военного образования}

В статье исследуются актуальные проблемь определения структуры, сущности и содержания основных законов дидактики в сфере высшего военного образования в условиях 
модернизации отечественной высшей военной школы, а также в связи с необходимостью повышения эффективности функционирования системы высшего военного образования $и$ качества подготовки военных специалистов в соответствии $c$ требованиями профессионализации сил оборонь с максимальным использованием опыта применения передовых технологий и методик подготовки соискателей военного образования в армиях стран-членов НАТО.

Ключевые слова: законы дидактики; обеспечение качества выстего военного образования; гарантия качества высшего военного образования; компетентность соискателя высшего военного образования.

\title{
SUMMARY
}

\author{
Andrii Zelnytskyi, \\ PhD (Pedagogical Sciences), Professor \\ National Defence University of Ukraine \\ named after Ivan Cherniakhovskyi, c. Kyiv \\ Oleh Zabolotnyi, \\ PhD (Military Sciences), Associate Professor \\ National Defence University of Ukraine \\ named after Ivan Cherniakhovskyi, c. Kyiv \\ Nadiya Shabatina, \\ National Defence University of Ukraine \\ named after Ivan Cherniakhovskyi, c. Kyiv
}

\section{The laws of didactics: state and development trends in the field of higher military education}

The article deals with the urgent problems of determining the structure, essence and content of the basic laws of didactics in the field of higher military education in the context of the modernization of the national higher military school, as well as in connection with the need to improve the functioning of the higher military education system and the quality of training of military specialists in accordance with the requirements of defense forces professionalization with the maximum use of experience in the application of advanced technologies and training methods for applicants of military education in the armies of NATO state-members..

Introduction. The article deals with problems of determining the structure, essence and content of the basic laws of didactics in the field of higher military education in the context of the modernization of the national higher military school, as well as in connection with the need to improve the functioning of the higher military education system and the quality of training of military specialists.

Purpose. The purpose of the article is to investigate the essence, content and interrelation of the basic laws of didactics in the holistic system of quality of higher military education and also taking into account new technologies in pedagogy.

Methods. The theoretical methods such as: analysis and synthesis, induction and deduction, comparison, classification, generalization and systematization, idealization, abstraction were used during the research.

Results. The essence, content and interrelation of the basic laws of didactics in the system of higher military education are investigated. Also, the model of Military Education Quality System is presented in the article.

Originality. The internal and external factors, which influence on the quality of military education and the model of Military Education Quality System are presented for the first time.

Conclusion. The article presents the general theoretical views on the system of military education quality and also considers the basic laws of didactics, its essence, content and meaning in the holistic system of quality of higher military education. 
Key words: didactic laws; quality assurance of higher military education; quality assurance of higher military education; competence of the applicant for higher military education. 